\title{
Physiological Manipulation and Yield Response of Wheat Grown with Split Root System under Deficit Irrigation
}

\author{
Rashid Iqbal ${ }^{1,2}$, Mathias Neumann Andersen ${ }^{*}$, Muhammad Aown Sammar Raza ${ }^{2}$ Muhammad Adil \\ Rashid $^{1}$ and Salman Ahmad ${ }^{2}$
}

${ }^{1}$ Department of Agroecology, Aarhus University, Blichers Alle 20, 8830, Tjele, Denmark; ${ }^{2}$ Department of Agronomy, University College of Agriculture and Environmental Sciences, The Islamia University of Bahawalpur, Pakistan.

\begin{abstract}
Water shortage is the main limitation for agricultural production in many parts of the world. Drought or unavailability of water may seriously limit plant growth as well as yield. A pot experiment was carried out to evaluate the effects of various irrigation strategies i.e. Full (FI), deficit (DI) and partial rootzone drying (PRD) on physiological, water relations, water use efficiency (WUE), and yield related attributes of wheat. These irrigation treatments were started at anthesis stage and maintained for 30 days. For FI and DI, 100 and $50 \%$ of evapotranspiration (ET) was replaced by irrigating the entire pot surface every 4-5 days. For PRD, root system was split into two equal halves and during each irrigation event, only one-half of the root system was irrigated with the same amount of water as applied to DI, and subsequently, irrigation was switched to the second half. PRD irrigation significantly improved WUE (both photosynthetic and intrinsic) and instantaneous carboxylation efficiency of Rubisco than FI and DI. Higher Abscisic acid (ABA) production under $\mathrm{PRD}$ reduced stomatal conductance, net photosynthesis and transpiration rate. Magnitude of osmotic adjustment (i.e. leaf water, osmotic and tugor potential) was lowest and highest under FI, DI and PRD, respectively. However, PRD had lower shoot biomass and grain yield per plant as compared to FI but higher than the DI. Despite improving the WUE, PRD tended to compromise the yield of wheat crop but PRD is recommended instead of DI. Results imply that PRD treatment can be an option under water shortage; however, its suitability and efficacy should further be tested under field conditions.

Received | February 23, 2019; Accepted | July 08, 2019; Published | August 11, 2019

*Correspondence | Mathias Neumann Andersen, Department of Agroecology, Aarhus University, Blichers Alle 20, 8830, Tjele, Denmark; Email: mathiasn.andersen@agro.au.dk

Citation | Iqbal, R., M.N. Andersen, M.A.S. Raza, M.A. Rashid and S. Ahmad. 2019. Physiological manipulation and yield response of wheat grown with split root system under deficit irrigation. Pakistan Journal of Agricultural Research, 32(3): 514-526.

DOI | http://dx.doi.org/10.17582/journal.pjar/2019/32.3.514.526

Keywords | Leaf gas exchange, Water use efficiency, Irrigation strategies, Osmotic adjustment, Grain yield
\end{abstract}

\section{Introduction}

W Theat is an imperative grain crop and a staple food of many countries around the globe. Water scarcity during the anthesis stage of wheat reduces the grain production. Due to low rainfall and ever rising temperature, the risk of drought at anthesis or post anthesis stages of wheat is alarming in semi arid areas of the world. Drought stress at anthesis stage causes the abortion of wheat grains (Rajala et al., 2009) and also affects the process of grain filling. It results in grain shrinkage (dried-up) and responsible for reduction in grain yield (Dias de Oliverira et al., 2013; Mitchell et al., 2013). Water is the key element in determining the wheat yield when it is used at anthesis or post anthesis stage (Manschadi etal.,2006).

Threats of drought for agricultural production are 
increasing with ever-increasing demand of more food, feed, and fiber for world population (Wilhite and Buchanan-Smith, 2005). It is necessary to find out new techniques and methods that improve water use efficiency and conserve water resources for agriculture in the future. Adaptation of these types of methods might be the excellent to combat the drought (Nasrullah et al., 2011). To some extent, drought stress can be ameliorated by use of various nutrients (Raza et al., 2012a), some harmless plant solutes (Raza et al., 2012b) and proper mulching is also helpful for agricultural production in water scarce conditions globally (Schahbazian and Nejad, 2006).

To tackle with drought stress, partial root zone drying (PRD) is an irrigation method in which half of the roots of plants are irrigated and the remaining half of the roots are left to dry to initiate biochemical signaling by ABA (Dry et al., 2000). It can maintain the water status in plants by increasing the $A B A$ concentration and thereby induce partial closure of stomata to reduce the transpiration rate (Dry et al., 2000). Due to stomatal closure, the photosynthesis process is affected (Liu et al., 2005) but often there is no significant difference of final yield between PRD and control treatment, ultimately PRD boosts the water use efficiency of various crop plants.

Full irrigation is practiced in most of the areas of world due to availability of sufficient water resources and crops receive their full evapotranspiration requirements with production eventually reaching its full potential. There is no stress on crops using full irrigation method but this luxury type of watering should be modified into other irrigation system that has minimum effect on final yield of agricultural crops (Kang and Zhang, 2004). Most of the research has been carried out to evaluate the effectiveness and productivity of various water conservation techniques but some are still continued (Sleper et al., 2007).

Water-saving agricultural irrigation systems are practiced now a day to increase WUE of crops. Partial root zone drying (PRD) and deficit irrigation (DI) are considered the best one water saving irrigation strategies that lessen the water requirement as compared to full irrigation without affecting the yield and water productivity (Ahmadi et al., 2010). Physiological responses of plants and elevated concentration of ABA are used to compute the switching time of PRD alteration from dry roots to wet and vice versa (Holbrook et al., 2002). The dry portion of roots maintain the ABA concentration and wet portion supply the water on regular basis and keep the water status of plant.

Deficit irrigation system is commonly used in water limited areas of world and has a high value in agriculture production that enhances the water use efficiency in comparison of full irrigation system with significant yield reduction (Geerts and Raes, 2009). The PRD is the modified form of deficit irrigation but it yielded well (Yazar et al., 2009). In DI, same amount of water that is used for PRD is given to both sides of roots. This is also water deficient condition which can produce ABA but in low concentration as in PRD (Saeed et al., 2008). Abscisic acid (ABA) produced under stress condition and carried to leaves through the xylem vessels where it functions as osmotic adjustments (Schachtman and Goodger, 2008). Practical results for PRD and DI reveal that PRD improve the crop production and WUE more efficiently in comparison of DI if equal amount of water is used (Sepaskhah and Ahmadi, 2010; Adu et al., 2018).

Soil water content is the key element that controls the leaf gas exchange, dry matter contents (DMC), grain yield/shoot biomass per plant and water use efficiency (Qiu et al, 2008). By improving the soil water content elevated photosynthetic characteristics and more grain filling can be achieved with higher grain yield of winter wheat (Lou et al., 2011; Xue et al., 2006). Research studies showed that water stress during wheat anthesis reduce down the photosynthetic values and senescence of flag leaf (Wu et al., 2014; Yang et al., 2000).

Water use efficiency of wheat is mostly linked with intercellular carbon concentrations (more carbon concentration causes more photosynthesis) and transpiration rate which is generally dependent to stomatal conductance (de Santana et al., 2015; Flexas et al., 2013). This photosynthetic rate and transpiration is mostly controlled by the irrigation levels (Monneveux et al., 2006). So, more WUE is the possible technique to improve the crop performance in water scarce areas world widely (Araus et al., 2002). In many parts of wheat growing regions in the world prone to terminal drought during anthesis stage or having very low water resources for irrigation at this stage. The objectives of the current study were 
to investigate the physiological and yield response of wheat using various irrigation strategies, and to select the deficit irrigation or partial root zone drying irrigation for the arid and semi-arid environments for wheat production.

\section{Materials and Methods}

\section{Partitioned pot design}

The cylindrical pot was used having the volume of $8.5 \mathrm{~L}(15 \mathrm{~cm}$ outer diameter and $48 \mathrm{~cm}$ deep) and was divided into two equal vertical compartments by a plastic sheet. This plastic sheet prevented the exchange of water movement between the two compartments. The bottom of the pots was covered with $1.5 \mathrm{~mm}$ nylon mesh. Six wheat plants were maintained in each pot, three plants were at one side of the plastic sheet and other three were on other side of the plastic sheet at a distance of $2 \mathrm{~cm}$. Drip irrigation was installed at the time of treatment application.

\section{Plant material and cultivation of wheat}

Empty plastic pots were weighted and filled with 12.9 $\mathrm{kg}$ sieved soil. Each compartment of pot contained $6.4 \mathrm{~kg}$ of dry soil. The soil was classified as sandy loam with $68 \%$ sand, $24.3 \%$ silt and $7.7 \%$ clay. The chemical characteristics of this soil were as follows, total carbon $16.3 \mathrm{~g} / \mathrm{kg}$, total nitrogen $1.5 \mathrm{~g} / \mathrm{kg}$ and water soluble phosphorus $6.3 \mathrm{mg} / \mathrm{kg}$. The field capacity (after 2 days drainage on a natural moist soil surface) and wilting point (pressure plate apparatus) of this soil at $\mathrm{pF}, 2$ and 4 were $25.3 \%$ and $6.7 \%$ respectively. The water retention curve for this experiment was made. Each pot was filled to a dry bulk density of about $1.3 \mathrm{~g} / \mathrm{cm}^{3}$. Inorganic liquid fertilizers having both the macro and micronutrients were applied after 25 and 40 days of sowing at the rate of $200 \mathrm{~kg} \mathrm{~N}, 34 \mathrm{~kg} \mathrm{P}$ and $158 \mathrm{~kg}$ of $\mathrm{P}$ on hectare basis. This experiment was carried out in glasshouse conditions at Research Centre Foulum, Aarhus University, Denmark. Twelve seeds of wheat variety Taifun were sown in each plastic pot. After the germination, thinning was done to keep the required plant population (same size and same growth) of six plants per pot. Plants were sprayed to avoid the powdery mildew. All other agronomic practices were kept maintained during the whole experiment.

\section{Experimental setup}

The present experiment was planned to study the effects of different irrigation strategies on the water relations, physiology and yield attributes of wheat (cv. Taifun) in special designed plastic pots. These treatments were carried out during the anthesis stage of wheat. Soil moisture content was monitored on regular basis with the help of Time Domain Reflectometry (TDR, Campbell Scientific, UT, USA) for which one probe consisting of two steel rod of $40 \mathrm{~cm}$ length were installed in each pot, while two probes (one in each compartment) were used in the PRD pots. Experiment was carried out in a climate (temperature and humidity) controlled glasshouse. The temperature and humidity ranges were between $22-10{ }^{\circ} \mathrm{C}$ and $75 \%-50 \%$ at day and night time with photosynthetic active radiations (PAR) supplied with the sun and metal-halide lamps. Hot air blowers were used at maturity stage of wheat crop.

\section{Treatments}

Stages of plant development were noted weekly during the experiment. All the plants were kept at $100 \%$ pot water holding capacity until the anthesis stage. When they reached the anthesis stage, the treatments were applied using drip irrigation. In FI (full irrigation or control treatment), both soil compartments were irrigated to pot water holding capacity after 4-5 days by drip irrigation with tap water supplied in the middle of the pot. In PRD (partial root zone drying treatment), half of the root system of plant were watered to pot water holding capacity while the other half was allowed to dry to c. $8 \%$ volumetric water content as measured by the TDR system. This lasted about 4-5 days, after which the irrigation was switched to the other side of the pot. PRD was applied in all the cycles/phases at 50\% of FI (half amount of water). In DI (deficit irrigation): the same amount of water as used for PRD (50\% of FI) was applied evenly in both sides of the pots by irrigation in the middle of the pot. Each pot was watered after the calculation of soil moisture deficit. The three treatments had 10 replicates so that a total of 30 experimental pots were used. All the pots were irrigated until the end of the experiment. All the pots were kept on trolleys (two pots per trolley) and trolleys were repositioned regularly during the experiment to compensate for possible unequal light distribution in the glass house.

\section{Measurements and statistical analysis}

Physiological traits of flag leaves: Irrigation treatments were started at anthesis stage and were lasted for 30 days. After completing the treatments, the Flag leaf was selected from each treatment $(n=10)$ for leaf gas exchange measurements (stomatal 
conductance $\left(\mathrm{g}_{\mathrm{s}}\right)$, net photosynthesis $\left(\mathrm{A}_{\mathrm{n}}\right)$, leaf temperature $\left(\mathrm{L}_{\mathrm{t}}\right)$, transpiration $\left(\mathrm{T}_{\mathrm{r}}\right)$, Intercellular $\mathrm{CO}_{2}$ concentration $(\mathrm{Ci})$. All these physiological measurements were taken with the help of CIRAS-2 portable photosynthesis system (PP system Inc. MA, USA) using light intensity of $1500 \mu \mathrm{molm}^{-2} \mathrm{~s}^{-1}$.

\section{Leaf Water Use Efficiency $\left(\mathrm{WUE}_{\mathrm{L}}\right)$ : Leaf} photosynthetic and intrinsic water use efficiencies were defined and calculated from the following equations i.e.

1. Photosynthetic water use efficiency (WUEp): It is commonly calculated by dividing the net photosynthetic rate of leaf by the transpiration rate of leaf.

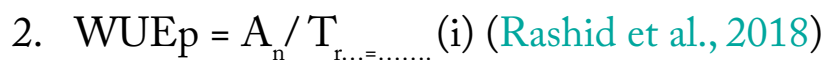

3. Intrinsic water use efficiency (WUEi): To compute the intrinsic WUE, the net photosynthesis of flag leaf is divided by the stomatal conductance.

4. $\mathrm{WUEi}=\mathrm{A}_{\mathrm{n}} / \mathrm{g}_{\mathrm{s} . . . . .}$ (ii) (Rashid et al., 2018)

5. Instantaneous carboxylation efficiency of Rubisco (CEi): It is derived by dividing the leaf photosynthesis with intercellular $\mathrm{CO}_{2}$ concentration.

6. $\mathrm{CEi}=\mathrm{A}_{\mathrm{n}} / \mathrm{Ci} \ldots$... (iii) (Rashid et al., 2018)

lag leaf water relations: To measure the leaf water potential $\left(\psi_{\mathrm{w}} \mathrm{MPa}\right)$, flag leaves were enclosed in plastic bags and cut from each treatment $(n=10)$. They were then immediately inserted in a pressure chamber (Soil Moisture Corp, Santa Barbara, CA) and the pressure was raised slowly until the equilibrium was reached as observed through a binocular microscope. After reading the water potential, the leaves were enclosed in tinfoil and stored in liquid nitrogen. Later, the cell sap was extracted after thawing and solute/osmotic potential $\left(\psi_{s}, \mathrm{MPa}\right)$ was measured in a $\mathrm{C}-52$ sample chamber (WescorInc, Logan, UT, USA) with the help of a Dew Point Micro voltmeter (Wescor HR33T) as detailed by Andersen et al. (1991). Leaf turgor pressure/potential (MPa) was computed by the difference of water potential and osmotic potential as illustrated in the following equation.

- Leaf turgor potential or pressure potential $\left(\psi_{\mathrm{p}}\right)=$ $\left(\psi_{\mathrm{w}}\right)-\left(\psi_{\mathrm{s}}\right) \ldots \ldots$ (iv) (Raza et al., 2017).

\section{Yield related traits and harvest index}

Harvesting of the wheat crop was carried out when all the plants and grains in the spikelets reached maturity. Dried plant samples at maturity were taken from each treatment $(n=10)$ pot to measure the shoot biomass at maturity, spike length, number of spikelets per spike, grains in each spike, thousand grain weight and final grain yield. Harvest index of each wheat plant was also calculated from the below mentioned formula.

Harvest Index (H.I) $=$ Grain yield $/$ Shoot biomass at maturity

Leaf abscisic acid (ABA): Leaf ABA was determined by using the protocols described by Spiers et al. (2013).

\section{Statistical analysis (Statistix Version 9.1)}

Collected data of all the related parameters from each treatment $(\mathrm{n}=10)$ pot was analyzed by using Fisher's analysis of variance technique and LSD test at 5\% probability level was used to compare the differences among the treatments' means (Steel et al., 1997).

\section{Results and Discussion}

\section{Physiological traits from flag leaf}

Data related to stomatal conductance is shown in Table 1. Plants that were fully irrigated (FI) showed a higher maximum value $\left(328 \mathrm{mmolm}^{-2} \mathrm{~s}^{-1}\right)$ of stomatal conductance than both the water deficit treatments. Between the water stress treatments deficit irrigated (DI) plants had higher $\left(254 \mathrm{mmolm}^{-2} \mathrm{~s}^{-1}\right)$ stomatal conductance than the partial root zone drying $\left(101 \mathrm{mmolm}^{-2} \mathrm{~s}^{-1}\right)$ irrigation. Irrigation strategies also significantly affected the leaf photosynthetic process. Higher stomatal conductance is often related to higher value of net photosynthesis in crop plants as higher value of net photosynthetic rate $\left(12.8 \mu \mathrm{molm}^{-}\right.$ $\left.{ }^{2} \mathrm{~s}^{-1}\right)$ was attained in FI plants followed by DI plants $\left(9.8 \mu \mathrm{molm}^{-2} \mathrm{~s}^{-1}\right)$ and minimum value of net photosynthesis $\left(6.2 \mu \mathrm{molm}^{-2} \mathrm{~s}^{-1}\right)$ was achieved in PRD treated plants due to more stomatal closure (Table 1).

Flag leaf temperature and transpiration rate was significantly affected by all three irrigation treatments (Table 1). Lowest value of flag leaf temperature $\left(17.6^{\circ} \mathrm{C}\right)$ was attained in the FI treatment with maximum transpiration rate $\left(3.0 \mathrm{mmolm}^{-2} \mathrm{~s}^{-1}\right)$. Moderate flag leaf temperature $\left(21.0^{\circ} \mathrm{C}\right)$ was observed in the DI treatment with lower transpiration rate $\left(2.1 \mathrm{mmolm}^{-2} \mathrm{~s}^{-1}\right)$ than the FI treatment. The highest flag leaf temperature $\left(27.2^{\circ} \mathrm{C}\right)$ was recorded in the PRD treatment with lowest transpiration rate $\left(0.9 \mathrm{mmolm}^{-2} \mathrm{~s}^{-1}\right)$. Higher stomatal conductance was 
Table 1: Effect of various irrigation strategies on leaf photosynthetic parameters of wheat $(n=10)$.

\begin{tabular}{|c|c|c|c|c|c|}
\hline Treatments & $\begin{array}{l}\text { Stomatal conduct- } \\
\text { ance }\left(\mathrm{mmolm}^{-2} \mathrm{~s}^{-1}\right)\end{array}$ & $\begin{array}{l}\text { Photosynthetic } \\
\text { rate }\left(\mu \mathrm{molm}^{-2} \mathrm{~s}^{-1}\right)\end{array}$ & $\begin{array}{l}\text { Flag leaf tem- } \\
\text { perature }\left({ }^{0} \mathrm{C}\right)\end{array}$ & $\begin{array}{l}\text { Transpiration rate } \\
\left(\mathrm{mmolm}^{-2} \mathrm{~s}^{-1}\right)\end{array}$ & $\begin{array}{l}\text { Intercellular } \mathrm{Co}_{2} \mathrm{Con}- \\
\text { centration }\left(\mu \mathrm{mol} \mathrm{Co} \mathrm{Co}_{2}\right)\end{array}$ \\
\hline FI(Full Irrigation) & $328 \mathrm{~A}$ & $12.8 \mathrm{~A}$ & 17.6 C & $3.0 \mathrm{~A}$ & $338 \mathrm{~A}$ \\
\hline DI(Deficit Irrigation) & $254 \mathrm{~B}$ & $9.8 \mathrm{~B}$ & $21.0 \mathrm{~B}$ & $2.1 \mathrm{~B}$ & $287 \mathrm{~B}$ \\
\hline $\begin{array}{l}\text { PRD (Partial Root zone } \\
\text { Drying) }\end{array}$ & $101 \mathrm{C}$ & $6.2 \mathrm{C}$ & $27.2 \mathrm{~A}$ & $0.9 \mathrm{C}$ & $163 \mathrm{C}$ \\
\hline ANOVA Summary & $* *$ & $* *$ & $* *$ & $* *$ & $* *$ \\
\hline $\begin{array}{l}\text { LSD ( at } 5 \% \text { probability } \\
\text { level) }\end{array}$ & 28 & 0.90 & 0.83 & 0.14 & 23 \\
\hline
\end{tabular}

Means not sharing the same letter are significantly different at $p<0.05$ within each column.

Table 2: Effect of various irrigation strategies on leaf water use efficiency of wheat $(n=10)$.

\section{Treatments}

FI(Full Irrigation)

DI(Deficit Irrigation)

PRD (Partial Root zone Drying)

ANOVA Summary

LSD ( at 5\% probability level)
Photosynthetic water use effi- Intrinsic water use efficien- Instantaneous carboxylation ciency $\left(\mu \mathrm{mol} \mathrm{Co} \mathrm{mmol}^{-1} \mathrm{H}_{2} \mathrm{O}\right)$ cy $\left(\mu \mathrm{mol} \mathrm{Co}_{2} \mathrm{mmol}^{-1} \mathrm{H}_{2} \mathrm{O}\right)$ efficiency $(\mathrm{CEi})=\left(\mathrm{A}_{\mathrm{n}} / \mathrm{Ci}\right)$

4.7C

$0.038 \mathrm{~B}$

$0.037 \mathrm{~A}$

$4.6 \mathrm{~B}$

$0.038 \mathrm{~B}$

$0.034 \mathrm{~B}$

$6.7 \mathrm{~A}$

$0.067 \mathrm{~A}$

$0.039 \mathrm{~A}$

***

0.30

0.0071

Means in the column not sharing the same letter are differ significantly at $p<0.05$ within each column.

Table 3: Effect of various irrigation strategies on flag leaf water relations of wheat $(n=10)$.

$\begin{array}{llll}\text { Treatments } & \begin{array}{l}\text { Leaf water potential, } \boldsymbol{\psi}_{\mathrm{w}} \\ (\mathbf{M P a})\end{array} & \begin{array}{l}\text { Leaf osmotic potential, } \boldsymbol{\psi}_{\mathrm{s}} \\ (\mathbf{M P a})\end{array} & \begin{array}{l}\text { Leaf turgor potential } \\ \left(\boldsymbol{\psi}_{\mathrm{p}}\right)(\mathbf{M P a})\end{array} \\ \text { FI(Full Irrigation) } & -0.38 \mathrm{C} & -1.36 \mathrm{C} & 0.98 \mathrm{~A} \\ \text { DI(Deficit Irrigation) } & -1.72 \mathrm{~A} & -2.00 \mathrm{~A} & 0.33 \mathrm{~B} \\ \text { PRD (Partial Root zone Drying) } & -1.22 \mathrm{~B} & -1.55 \mathrm{~B} & 0.28 \mathrm{~B} \\ \text { ANOVA Summary } & * * & * * & * * \\ \text { LSD (at 5\% probability level) } & 0.091 & 0.097 & 0.098\end{array}$

Means in the column not sharing the same letter are differ significantly at $p<0.05$ within each column.

also related to higher intercellular $\mathrm{CO}_{2}$ concentration. Irrigation strategies also affected the intercellular carbon dioxide. The highest value of $\mathrm{CO}_{2}$ concentration $\left(338 \mu \mathrm{mol} \mathrm{CO} \mathrm{CO}_{2}\right)$ was observed in fully irrigated wheat plants followed by deficit irrigated plants $(287 \mu \mathrm{mol}$ $\left.\mathrm{CO}_{2}\right)$ while the lowest value $\left(163 \mu \mathrm{mol} \mathrm{CO}_{2}\right)$ was attained under PRD before the last irrigation.

\section{Leaf Water use Efficiency (WUE}

Photosynthetic water use efficiency (WUEp) has shown in Table 2, indicated statistically significant differences between irrigation strategies. PRD had the highest values of photosynthetic water use efficiency $\left(6.7 \mu \mathrm{mol} \mathrm{CO} \mathrm{mmol}^{-1} \mathrm{H}_{2} \mathrm{O}\right)$ followed by DI $\left(4.6 \mu \mathrm{mol} \mathrm{CO} \mathrm{mmol}^{-1} \mathrm{H}_{2} \mathrm{O}\right)$ treatment and the lowest value $\left(4.7 \mu \mathrm{mol} \mathrm{CO} \mathrm{mmol}^{-1} \mathrm{H}_{2} \mathrm{O}\right)$ of WUEp was attained by the FI treatment. Partial root zone drying (PRD) also got more value of intrinsic water use efficiency than DI and FI. Intrinsic water use efficiency (WUEi) was highest $\left(0.067 \mu \mathrm{mol} \mathrm{Co}_{2}\right.$ $\mathrm{mmol}^{-1} \mathrm{H}_{2} \mathrm{O}$ ) in PRD but there was no significant difference of WUEi between DI and FI irrigation strategies. Instantaneous carboxylation efficiency of Rubisco $(\mathrm{CEi})$ was highest in PRD $\left(0.039 \mathrm{~A}_{\mathrm{n}} / \mathrm{Ci}\right)$ and FI $\left(0.037 \mathrm{~A}_{\mathrm{n}} / \mathrm{Ci}\right)$ compared to DI $\left(0.034 \mathrm{~A}_{\mathrm{n}}^{\mathrm{n}} / \mathrm{Ci}\right)$ treatment (Table 2).

\section{Flag leaf water relations}

Flag leaf water relations of wheat were significantly different from each other at FI, DI and PRD (Table $3)$. More negative water potential $(-1.72 \mathrm{MPa})$ was recorded in $\mathrm{DI}$ treatment followed by $\mathrm{PRD}$ irrigation $(-1.22 \mathrm{MPa})$. The highest value of leaf water potential $(-0.38 \mathrm{MPa})$ was recorded in FI treatment. 
Table 4: Effect of various irrigation strategies on yield traits and harvest index of wheat $(n=10)$.

\begin{tabular}{|c|c|c|c|c|c|c|c|}
\hline Treatments & $\begin{array}{l}\text { Spike length } \\
\text { (cm) }\end{array}$ & $\begin{array}{l}\text { Spikelets num- } \\
\text { ber per spike }\end{array}$ & $\begin{array}{l}\text { Grains } \\
\text { per spike }\end{array}$ & $\begin{array}{l}\text { 1000-Grain } \\
\text { weight (g) }\end{array}$ & $\begin{array}{l}\text { Grain yield per } \\
\text { plant }(\mathrm{g})\end{array}$ & $\begin{array}{l}\text { Shoot biomass } \\
\text { per plant }(\mathrm{g})\end{array}$ & $\begin{array}{l}\text { Harvest } \\
\text { Index (HI) }\end{array}$ \\
\hline FI (Full Irrigation) & $20.3 \mathrm{~A}$ & $19.8 \mathrm{~A}$ & $57.6 \mathrm{~A}$ & $50.4 \mathrm{~A}$ & $27.0 \mathrm{~A}$ & $50.9 \mathrm{~A}$ & $0.53 \mathrm{~A}$ \\
\hline DI(Deficit Irrigation) & $16.5 \mathrm{~B}$ & $10.9 \mathrm{C}$ & $41.3 \mathrm{C}$ & $33.3 \mathrm{C}$ & $14.4 \mathrm{C}$ & $36.2 \mathrm{C}$ & $0.40 \mathrm{~B}$ \\
\hline $\begin{array}{l}\text { PRD (Partial Root } \\
\text { zone Drying) }\end{array}$ & $11.8 \mathrm{C}$ & $16.6 \mathrm{~B}$ & $52.1 \mathrm{~B}$ & $47.5 \mathrm{~B}$ & $24.71 \mathrm{~B}$ & $46.8 \mathrm{~B}$ & $0.53 \mathrm{~A}$ \\
\hline ANOVA Summary & ** & $* *$ & ** & $* *$ & ** & $* *$ & $* *$ \\
\hline $\begin{array}{l}\text { LSD ( at } 5 \% \text { probabili- } \\
\text { ty level) }\end{array}$ & 1.2 & 1.3 & 2.5 & 2.3 & 1.6 & 3.5 & 0.019 \\
\hline
\end{tabular}

Means in the column not sharing the same letter are differ significantly at $p<0.05$ within each column.

The irrigation strategies also affected the leaf osmotic potential differently and lowest values of osmotic potential $(-2.00 \mathrm{MPa})$ was measured in DI treatment followed by PRD $(-1.55 \mathrm{MPa})$ while FI had the highest value $(-1.36 \mathrm{MPa})$ of the three irrigation strategies. Both of the stress treatments (DI and PRD) had low values of turgor pressure/potential. Maximum turgor potential $(-0.98 \mathrm{MPa})$ was measured in FI treatment. There was no significant difference of turgor potential between the two stress treatments.

\section{Yield related traits and harvest index}

Significant effect of irrigation strategies on all yield traits and harvest index was detected (Table 4). Longer wheat spikes $(20.3 \mathrm{~cm})$ were obtained in FI than DI $(16.5 \mathrm{~cm})$ and PRD $(11.8 \mathrm{~cm})$. Although spikes were longer in $\mathrm{DI}$ than in $\mathrm{PRD}$, the number of spikelets per spike and retention of wheat grains was higher in PRD treatment (Table 4). More spikelets per spike (19.8) and grains per spike (57.6) were obtained in FI followed by PRD $(16.6,52.1)$ and DI $(10.9,41.3)$, respectively.

1000-grain weight also showed significant differences amongst the irrigation strategies. Highest value (50.4 g) of 1000-grain weight was attained in FI followed by PRD (47.5 g) and lowest value (33.2 g) was found in DI. Highest grain yield per plant $(26.975 \mathrm{~g})$ was reached in FI (27.0) followed by PRD $(24.7 \mathrm{~g})$ and DI (14.4 g) (Table 4).

Shoot biomass per plant varied in the same pattern as grain yield between irrigation strategies. Highest value of shoot biomass per plant $(50.9 \mathrm{~g})$ was observed in FI followed by PRD (46.8 g) and DI (36.2 g). Harvest index values of FI and PRD (both 0.53 ) were the same indicating the efficiency of PRD treatment to maintain a high harvest index as high as FI. Lower value of harvest index (0.40) was recorded in DI (Table 4).
Figure 1 is related to leaf abscisic acid (ABA) concentration $\left(\mathrm{ng} \mathrm{g}^{-1}\right)$ in wheat leaves. It indicates that irrigation strategies had significant effects on abscisic acid (ABA) concentration in wheat leaves. Maximum values of leaf abscisic acid (ABA) concentration $\left(914.50 \mathrm{ng} \mathrm{g}^{-1}\right)$ of wheat was achieved with partial root zone drying (PRD) irrigation strategy followed (446.20 $\mathrm{ng} \mathrm{g}^{-1}$ ) by deficit irrigation (DI) and minimum (186.40 $\mathrm{ng} \mathrm{g}^{-1}$ ) values of abscisic acid (ABA) concentration was achieved in full irrigation (FI).

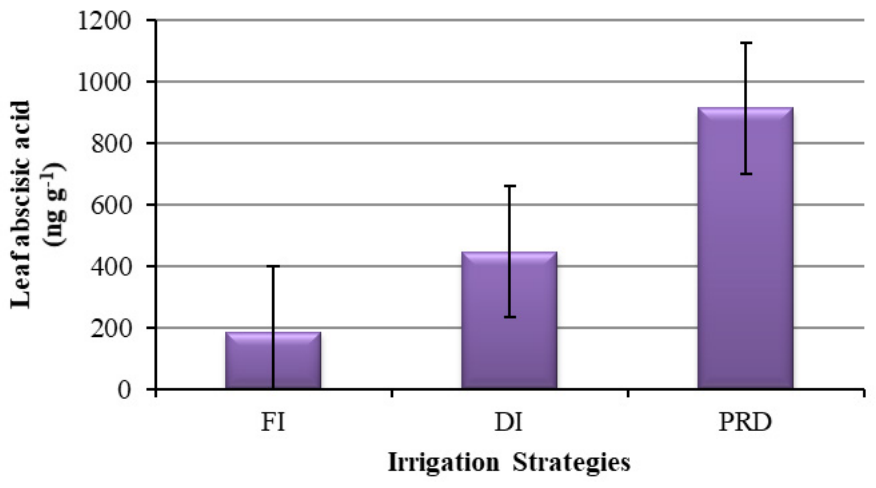

Figure 1: Leaf abscisic acid (ABA) concentration $\left(n g g^{-1}\right)$ in wheat $(n=10)$ leaves under various irrigation strategies. Error bars represent the standard error of the treatments means.

Water deficiency has detrimental effects on some physiological processes of wheat crop as compared to partial rhizosphere drying or fully irrigated plants. Water deficiency causes the reduction in crop production and final grain yield by affecting the photosynthetic rate. Among the many physiological processes occurring in the plant body stomatal conductance shows clear evidences of crop responses in water deficit situation (Baloch et al., 2012). Stomata are very minute pores in plants that are supportive in swap over gases between the plant and their ecological surrounding. They are also helpful for transpiration and carbon dioxide influx (Nilson and Assmann, 2007). These minute pores also cause the cooling effect in the surroundings. Fully irrigated plants attained 
$22.44 \%$ and $69.16 \%$ more stomatal conductance in relation to deficit and partial root zone irrigated plants respectively. DI treated plants attained $60.24 \%$ more stomatal conductance than PRD treatment. Abscisic acid (ABA) production in PRD applied treatment is assumed the main factor for partial closure of stomata and water is saved from being transpired through stomata openings (Tang et al., 2005; Saeed et al., 2008; Du et al., 2008; Raza et al., 2017). ABA is the main stress signal of dry roots which also cause the deficiency of potassium ions in the guard cells. No doubt, the stomatal conductance is reduced in the plant body but there is no significant effect of this on photosynthetic rate, final yield and WUE of PRD treated plants in relation to FI plants (Davies et al., 2002; Costa et al., 2007; Ahmadi et al., 2010).

Photosynthetic rate and stomata resistance/ conductance are not so much affected by partial stomata closure due to PRD or low availability of water content. Photosynthesis is mostly affected by severe water stress in plant leaves. It is the main predictor of overall growth, physiology and final yield of crop plants. Full irrigated treatment achieved $23.37 \%$ and $51.21 \%$ more values of photosynthetic rate as compared to deficit and $\mathrm{PRD}$ irrigation strategies, respectively. Between the water deficient treatments, DI attained $36.33 \%$ more photosynthesis than PRD. Water potential of leaves control the hydraulic conductivity of leaves, in severe water stress conditions the mesophyll cells drop their water potential and hence there is fast reduction in photosynthetic rate (Taiz and Zeiger, 2006). Higher ABA concentrations in PRD treated plants causes the partial closure of stomata and hence a reduction in photosynthesis takes place due to limited supply of carbon dioxide at carboxylation sites (Costa et al., 2007; Wang et al., 2005; Du et al., 2008; Tang et al., 2005; Saeed et al., 2008; Alkhaldi et al., 2012).

Plant leaves are capable to cause the cooling effects in surroundings. More the transpiration rate of the plant leaf more is the cooling effect with lower leaf temperature. PRD treated wheat plants got $22.90 \%$ and $35.52 \%$ more leaf temperature in relation to DI and FI irrigation strategies with low transpiration rates. DI attained $16.35 \%$ more leaf temperature as compared to FI. This phenomenon is also dependent on the stomatal oscillation in leaves. Although more transpiration causes cooling effect in environment at the same time transpire water from plant body. It is not suitable in water scarce areas. However, PRD have high leaf temperature but at the same time conserve more water by reducing the stomatal conductance or low transpiration rate.

Transpiration and water regulation in plants is mostly controlled by leaf area and stomatal regulations (Levitt,1980). More the leaf area/stomatal conductance means more water is transpired from the plants and hence higher the photosynthetic rate. FI treatment got $29.81 \%$ and $68.99 \%$ more transpiration rate in comparison of DI and PRD treatments. FI plants have the highest photosynthesis due to more transpirations or higher stomatal conductance. Between both the water stress treatments DI attained 55.82\% more tanspiration rate than PRD. Stomatal regulations control the transpiration simultaneously the intercellular carbon dioxide concentrations. So, FI attained $15.10 \%$ and $51.62 \%$ more intercellular carbon dioxide concentation as compared to DI and PRD but the DI got $43.02 \%$ more value of intercelluar carbon dioxide concentration than PRD. Carboxylation sites of leaves get low carbon dioxide in drought stressed treatments due to stomatal closure (Chaves and Oliveira, 2004; Ma et al., 2015).

There is an increased production of ABA during the drying phase of roots as in PRD as compared to normal conditions of soil (Davies and Zhang, 1991) and this $\mathrm{ABA}$ concentration is moved to upper parts of plants as an anti stress chemical signal of roots to limit the stomatal conductance and conserve the water in plants which otherwise transpire through stomatal openings (Liu et al., 2005). PRD applied treatment attained $51.20 \%$ and $79.61 \%$ more leaf ABA concentrations in relation to DI and FI treatment. The DI treatment obtained $58.22 \%$ more leaf ABA than the FI. Alternate wetting and drying of roots produce more $\mathrm{ABA}$ than any other irrigation system and this is the most efficient irrigation in arid/ semi-arid environment for sustainable production of crop plants. PRD has more positive effects in relation to DI in terms of quality and yield.

Water use efficiency (WUE) is commonly derived by the total dry matter production with maximum utilization of water. High values of WUE indicate an increased biomass production per unit of water used. Leaf WUE (Photosynthetic WUE and Intrinsic WUE) is an imperative characteristic of plants to know the drought tolerance capability of plants. 
PRD applied treatment attained 37.31\% and 31.23\% more photosynthetic WUE as compared to FI and DI applied irrigation strategies. Fully irrigated (FI) applied plants got $8.83 \%$ less photosynthetic WUE in relation to DI. As the intrinsic WUE is concerned, PRD plants attained $42.34 \%$ and $42.94 \%$ more values in comparison of FI and DI applied treatments but no significant difference (1.04\%) was attained in FI and DI for intrinsic WUE. Different scientists also observed the similar results of $\mathrm{PRD}$ technique in comparison of full irrigation for WUE (Ahmadi et al., 2010; Geerts and Raes, 2009; Davies et al., 2002; Zegbe et al., 2004; Sepaskhah and Khajehabdollahi, 2005; Shahnazari et al., 2007; Shani-Dashtgol et al., 2006; Costa et al., 2007; Fereres and Sariano, 2007).

Instantaneous carboxylation efficiency of rubisco is also an imperative indicator for stress tolerance in plants. It is mostly dependent on net photosynthesis of leaves and their intercellular carbon dioxide concentrations. PRD treated plants got absolutely equal value $(3.62 \%$ more) of carboxylation efficiency to $\mathrm{FI}$ but attained $12.17 \%$ more value than the DI applied treatment. DI achieved $8.87 \%$ less value of instantaneous carboxylation efficiency than FI treatment.

Leaf water and osmotic potentials has strong relations in plants. Leaf potential energy of water is typically computed by its water potential. A minute change in leaf osmotic potential also changes the leaf water potential. DI applied treatment achieved $28.87 \%$ and $77.76 \%$ more values of water potential in relation to $\mathrm{PRD}$ and FI, respectively. PRD attained $68.73 \%$ more values of water potential than full irrigation treatment. Same findings of PRD treated plants were also observed by various scientists in relation to control irrigation (Raza et al., 2017; Adu et al., 2018; Wakrim et al., 2005). Stikic et al. (2003) proposed contradictory results of leaf water potential and noted non-significant result between PRD and control irrigation.

Osmolites concentration in plant leaves is mostly related to leaf osmotic potential. Salinity decreases the osmotic potential in plant leaves as compared to fully irrigated plant leaves. The main phenomenon behind this is the reduction of cellular water in salt stress situation (Stoeva and Kaymakanova, 2008; Saleh, 2012). DI treatment got $22.29 \%$ and $31.76 \%$ more values of leaf osmotic potential as compared to
PRD and FI irrigation treatments, respectively. PRD achieved $12.18 \%$ more osmotic potential as compared to FI. Higher concentrations of osmolites in water deficient treatments (DI and PRD) is essentially due to the breakdown of larger sugar molecules in many number of smaller molecules that act as compatible osmolites and maintain the osmotic adjustment in plants (Raza et al., 2017; Chutia and Borah, 2012).

Leaf turgor potential has the ability to control all the physiological processes undergoing in plant body and helpful for more photosynthesis in crop plants (Raza et al., 2014). Both the leaf relative water content and leaf water potential control the tugor potential and turgidity of guard cells that control the stoma openings. Higher the turgidity in guard cells more is the gaseous exchange and vice versa. FI applied treatment attained $66.42 \%$ and $71.63 \%$ more values of leaf turgor potential in comparison of PRD and DI treatments, respectively. PRD got $15.50 \%$ more values of leaf turgor potential in relation to DI treatment. Similar findings were also proposed by Raza et al. (2017) using PRD and control irrigation in wheat cultivars.

Potential of wheat production is estimated by the grain retention in spikelet's in a single wheat spike. Spikelets number with maximum grain weight add huge share in final economic yield. Less spikelets number in a spike is generally due to less formation of spikelets primordial at tillering phase in water limited situation. Sometimes, low number of spikelets is due to the floret death at both ends of a spike (Maqbool et al., 2015). Water is the main limiting agent in this regards and that ultimately affect the productivity. Full irrigated treatment produced $16.16 \%$ and $44.94 \%$ more spikelets number per spike in comparison of PRD and DI, respectively. Between the water stress treatments partial root zone drying performed well and contributed $34.33 \%$ more spikelets per spike in relation to deficit irrigation treatment.

Limited water or more heat stress is the main factors that cause the abortion of wheat grains. Maximum grains retention in a spike is due to the availability of irrigation water or higher osmotic adjustment in plants which maintains the internal water status. Dehydration of pollen grains is also a limited factor for fewer grains in wheat spike (Khanzada et al., 2001). FI applied treatment got $9.62 \%$ and $28.35 \%$ more grains number per spike comparative of PRD and DI applied treatment in the experiment. PRD 
treatment gained $20.71 \%$ more grains number per spike in relation to DI treatment. This shows the efficiency of PRD irrigation strategy which is more efficient than the DI in water limited areas globally.

Maximum value of 1000 -grain weight shows the ability of wheat crop in water scarce situation. However, heavier grains are observed with high amount of irrigation water instead of drought stressed plants. More value of 1000 -grain weight is mostly due to more translocation of photosynthates which is generally dependent to the water availability in rhizosphere of plants. (Maqbool et al., 2015). FI irrigation system attained $5.75 \%$ and $34.03 \%$ higher value of 1000 -grain weight as compared to PRD and DI irrigation system. In PRD 50\% less irrigation water was consumed but there was not so higher difference of 1000-grain weight observed but significant effect was observed in DI applied treatment. PRD also got $30 \%$ more 1000-grain weight in comparison of deficit irrigation.

Grain yield/shoot biomass per plant is the result of various yield contributing parameters like length of wheat spike, spikelets in single spike and heavy grains retention in spikelets. Drought stress decreased the grain yield of wheat. Whenever, water deficit or drought stress comes to the plants they tend to complete their life cycle and maturation process enhancement occurs. In this situation plants have no time to easily or slowly complete the grain filling stage. It is also observed that in drought situation there is no maximum allocation of assimilates in plant. So, there is always less grains with low weight and in this condition final production always remain very low. Full irrigation treatment attained $8.46 \%, 46.57 \%$ more grain yield and $8.08 \%$, $28.86 \%$ more shoot biomass per plant in relation to PRD and DI treatment, respectively. At the moment, PRD achieved 41.63\%, 22.60\% more grain yield and shoot biomass per plant as compared to DI applied treatment. Harvest index shows the ability of a plant species to produce the economic portion from the total biomass of plant. Main concern of production is the valuable grain in wheat. Harvest index value shows that there is no significant difference (0.35\%) between FI and PRD but FI got 24.94\% more harvest index value than the DI. PRD also attained $24.67 \%$ more value of harvest index in relation to DI. PRD shows maximum water conservation by giving higher yield than DI with same amount of irrigation water.

\section{Conclusions and Recommendations}

PRD is exceptionally excellent irrigation method to conserve the water needed to crop plants and boosting the leaf water use efficiency (WUE). Higher growth, physiological and yield related parameters of wheat were observed in full irrigation applied treatment in comparison of PRD and DI. More ABA and osmotic adjustment was found in PRD treated plants than other irrigation strategies. Leaf WUE was also higher in PRD plants in comparison of FI and DI. PRD is most efficient irrigation method than DI in water limited areas world widely.

\section{Acknowledgement}

The research grant from Higher Education Commission of Pakistan and Aarhus University, Denmark for successful conductance and execution of research trial under international research support initiative program (IRSIP) is highly acknowledged.

\section{Authors Contribution}

Rashid Iqbal: Conceived theidea,overall management of the article, Data collection, initiated and finalized the paper.

Mathias Neumann Andersen: Provided technical input, supervised the research work, provided technical input at every step.

Muhammad Aown Sammar Raza: Data entry in SPSS and analysis, technical input.

Muhammad Adil Rashid: Technical Input, Write up. Salman Ahmad: Abstract, Introduction, References.

\section{References}

Adu, M.O., D.O. Yawson, F.A. Armah, P.A. Asare and K.A. Frimpong. 2018. Meta-analysis of crop yields of full, deficit and partial rootzone drying irrigation. Agric. Water. Manage. 197: 79-90. https://doi.org/10.1016/j. agwat.2017.11.019

Ahmadi, S.H., M.N. Andersen, F. Plauborg, R.T. Poulsen, C.R. Jensen, A.R. Sepaskhah and S. Hansen. 2010. Effects of irrigation strategies and soils on field grown potatoes: Gas exchange and xylem [ABA]. Agric. Water. Manage. 97: 1486-1494. https://doi.org/10.1016/j. agwat.2010.05.002

Andersen, M.N., C.R. Jensen and R. Losch. 1991. 
Derivation of pressure-volume curves by a nonlinear regression procedure and determination of apoplastic water. J. Exp. Bot. 42: 159-165. https://doi.org/10.1093/jxb/42.2.159

Alkhaldi, A., A.N. Aldarir, M. Janat, A. Wahbi and A. Arslan. 2012. Effect of regulated deficit irrigation and partial root-zone drying on some quantitative indicators and the efficiency of adding nitrogen fertilizer to (Zea mays L.) by using n15 Isotope. Am. Eur. J. Agric. Environ. Sci. 12: 1223-1235.

Araus, J.L., G.A. Slafer, M.P. Reynolds and C. Royo. 2002. Plant breeding and drought in C-3 cereals; what should we breed for? Ann. Bot. 89: 925-940. https://doi.org/10.1093/aob/mcf049

Baloch,M.J.,J.Dunwell,N.U.Khan,A.A.Khakwani, M. Dennett and W.A. Jatoi. 2012. Profiling dehydrin gene sequence and physiological parameters in drought tolerant and susceptible spring wheat cultivars. Pak. J. Bot. 2: 801-806.

Chaves, M.M. and M.M. Oliveira. 2004. Mechanisms underlying plant resilience to water deficits: prospects for water-saving agriculture. J. Exp. Bot. 55: 365-384. https:// doi.org/10.1093/jxb/erh269

Chutia, J. and S.P. Borah. 2012. Water stress effects on leaf growth and chlorophyll content but not the grain yield in traditional rice (Oryza sativa L.) Genotypes of Assam, India II. Protein and proline status in seedlings under peg induced water stress. Am. J. Plant. Sci. 3: 971-980. https://doi.org/10.4236/ajps.2012.37115

Costa, J.M., M.F. Ortuno and M.M. Chaves. 2007. Deficit irrigation as a strategy to save water: Physiology and potential application to horticulture. J. Integr. Plant. Bio. 49: 1421-1434. https://doi.org/10.1111/j.16729072.2007.00556.x

Davies, W.J., S. Wilkinson, B.R. Loveys. 2002. Stomatal control by chemical signaling and the exploitation of this mechanism to increase water use efficiency in agriculture. New phytol.153: 449-460. https://doi.org/10.1046/j.0028646X.2001.00345.X

de Santana, T.A., P.S. Oliveria, L.D. Silva, B.G. Laviola, A.F. de Almeida and F.P. Gomes. 2015. Water use efficiency and consumption in different Brazillian genotypes of Jatropha curcas L. subjected to soil water deficit. Biomass. Bioenerg. 75: 119-125. https://doi. org/10.1016/j.biombioe.2015.02.008
Davies, W.J. and J.H. Zhang. 1991. Root signals and the regulation of growth and development of plants in drying soil. Ann. Rev. Plant. Physiol. Plant. Mol. Biol. 42: 55-76. https://doi. org/10.1146/annurev.pp.42.060191.000415

Dias de Oliveira, E., H. Bramley, K.H.M. Siddique, S. Henty, J. Berger and J.A. Palta. 2013. Can elevated $\mathrm{Co}_{2}$ combined with high temperature ameliorate the effect of terminal drought in wheat? Funct. Plant. Biol. 40: 160-171. https:// doi.org/10.1071/FP12206

Dry, P.R., B.R. Loveys and H. During. 2000. Partial drying of the root zone of grape. II. Changes in the pattern of root development. Vitis. 39: 9-12.

Du, T., S. Kang, J. Zhang, F. Li and B. Yan. 2008. Water use efficiency and fruit quality of table grape under alternate partial root-zone drip irrigation. Agric. Water. Manage. 95: 659-668. https://doi.org/10.1016/j.agwat.2008.01.017

Fereres, E. and M.A. Soriano. 2007. Deficit irrigation for reducing agricultural water use. J. Exp. Bot. 58: 147-159. https://doi.org/10.1093/ jxb/er1165

Flexas, J., Niinemets, U., Galle, A., Barbour, MM., Centritto, M., Diaz-Espejo, A., Douthe, C., Galmes, J., Ribas-Carbo, M., Rodriguez, PL. 2013. Diffusional conductances to $\mathrm{CO}_{2}$ as a target for increasing photosynthesis and photosynthetic water-use efficiency. Photosynth. Res. 117: 45-59.

Geerts, S. and D. Raes. 2009. Deficit irrigation as an on-farm strategy to maximize crop water productivity in dry areas. Agric. Water. Manage. 96: 1275-1284. https://doi.org/10.1016/j. agwat.2009.04.009

Holbrook, M.N., V.R. Shashidhar, R.A. James and R. Munns. 2002. Stomatal control in tomato with ABA-deficient roots: response of grafted plants to soil drying. J. Exp. Bot. 53: 1503-1514. https://doi.org/10.1093/jxb/53.373.1503

Kang, S.Z. and J.H. Zhang. 2004. Controlled alternate partial root-zone irrigation: its physiological consequences and impact on water use efficiency. J. Exp. Bot. 55: 2437-2446. https://doi.org/10.1093/jxb/erh249

Khanzada, B., M.Y. Ashraf, S.A. Ala, S.M. Alam, M.U. Shirazi and M.U. Ansari. 2001. Water relations in different Guar (Cyamopsistetragonoloba L.) genotypes under water stress. Pak. J. Bot. 33: 279-287.

Liu, F., C.R. Jensen, A. Shahanzari, M.N. Andersen 
and S.E.Jacobsen.2005.ABA regulated stomatal control and photosynthetic water use efficiency of potato (Solanum tuberosum L.) during progressive soil drying. Plant. Sci. 168: 831-836. https://doi.org/10.1016/j.plantsci.2004.10.016

Levitt, J. 1980. Responses of plants to environment.2ed. Acad. Press, New York.

Lou, L., Z. Yu, D. Wang, Y. Zhang and Y. Shi. 2011. Effects of planting density and soil moisture on flag leaf photosynthetic characteristics and dry matter accumulation and distribution in wheat. Acta. Agron. Sin. 37: 1049-1059. https://doi. org/10.3724/SP.J.1006.2011.01049

Ma, S.C., A.W. Duan, R. Wang, Z.M. Guan, S.J Yang, S.T. Ma and Y. Shao. 2015. Root-sourced signal and photosynthetic traits dry matter accumulation and remobilization, and yield stability in winter wheat as affected by regulated deficit irrigation. Agric. Water. Manage. 148: 123-129. https://doi.org/10.1016/j. agwat.2014.09.028

Manschadi, A.M.,J. Christopher, P. deVoil and G.L. Hammer. 2006. The role of root architectural traits in adaptation of wheat to water-limited environments. Funct. Plant Biol. 33: 823-837. https://doi.org/10.1071/FP06055

Maqbool, M.M., A. Ali, T. Haq, M.N. Majeed and D.J. Lee. 2015. Response of spring wheat (Triticumaestivum L.) to induced water stress at critical growth stages. Sarhad. J. Agric. 31: 5358.

Mitchell, J.H., G.J. Rebetzke, S.C. Champan and S. Fukai. 2013. Evaluation of reduced tillering (tin) wheat lines in managed, terminal water deficit environments. J. Exp. Bot. 64: 34393451. https://doi.org/10.1093/jxb/ert181

Monneveux, P., D. Rekika, E. Acevedo and O. Merah. 2006. Effect of drought on leaf gas exchange, carbon isotope discrimination, transpiration efficiency and productivity in field grown durum wheat genotypes. Plant Sci. 170: 867-872. https://doi.org/10.1016/j. plantsci.2005.12.008

Nasrullah, M., M.B. khan, R. Ahmad, S. Ahmad, M. Hanif and W. Nazeer. 2011. Sustainable cotton production and water economy through different planting methods and mulching techniques. Pak. J. Bot. 43: 1971-1983.

Nilson, S.E. and S.M. Assmann. 2007. The control of transpiration: Insights from Arabidopsis. J. Plant. Physiol. 143: 19-27. https://doi.org/10.1104/ pp.106.093161

Qiu, G.Y., L.M. Wang, H.X. He, X.Y. Zhang, S.Y. Chen, J. Chen and Y.H. Yang. 2008. Water use efficiency and evapotranpiration of winter wheat and its response to irrigation regime in the north China plain. Agric. For. Meteorol. 148: 1848-1859. https://doi.org/10.1016/j. agrformet.2008.06.010

Rajala, A., K. Hakala, P. Makela, S. Murrinen and P. Peltonen-Sainio. 2009. Spring wheat response to timing of water deficit through sink and grain filling capacity. Field Crops Res. 114: 263-271. https://doi.org/10.1016/j.fcr.2009.08.007

Rashid, M.A., M.N. Andersen, B. Wollenweber, X. Zhang and J.E. Olesen. 2018. Acclimation to higherVPD and temperature minimized negative effects on assimilation and grain yield of wheat. Agric. For. Meteorol. 148: 119-129. https://doi. org/10.1016/j.agrformet.2017.09.018

Raza, M.A.S., S. Ahmad, M.F. Saleem, I.H. Khan, R. Iqbal, M.S. Zaheer, I. Haider and M. Ali. 2017. Physiological and biochemical assisted screening of wheat varieties under partial rhizosphere drying. Plant. Physiol. Biochem. 116: 150-166.

Raza, M.A.S., M.F. Saleem and S.A. Anjum. 2012b. Foliar application of potassium under water deficit conditions improved the growth and yield of wheat (Triticumaestivum L.). J. Anim. Plant. Sci. 22: 431-437.

Raza, M.A.S., M.F. Saleem and M.Y. Ashraf. 2012a. Glycine betaine applied under drought improved the physiological efficiency of wheat (Triticumaestivum L.). Plant. Soil. Environ. 31: 67-71.

Raza, M.A.S., M.F. Saleem, M. Jamil and I.H. Khan. 2014. Impact of foliar applied glycinebetaine on growth and physiology of wheat (Triticumaestivum L.) under drought conditions. Pak. J. Agric. Sci. 2: 327-334.

Saeed, H., I.G. Grove, P.S. Kettlewell and N.W. Hall. 2008. Potential of partial root zone drying as an alternative irrigation technique for potatoes (Solanumtuberosum L). Ann. Appl. Bot. 152: 71-80. https://doi.org/10.1111/j.17447348.2007.00196.x

Saleh, B. 2012. Salt stress alters physiological indicators in cotton (Gossypiumbirsutum L.). Soil. Environ. 2: 113-118.

Schachtman, D.P. and J.Q.D. Goodger. 2008. Chemical root to shoot signaling under drought. 
Trends. Plant. Sci. 13: 281-287. https://doi. org/10.1016/j.tplants.2008.04.003

Schahbazian, N. and H. Iran-Nejad. 2006. The effects of different mulch types and irrigation intervals on cotton yield. Die. Bod. 57: 765-766.

Sepaskhah, A.R. and S.H. Ahmadi. 2010. A review on partial root zone drying irrigation. Int. J. Plant. Prod. 4: 241-258.

Sepaskhah, A.R. and M.H. Khajehabdollahi. 2005. Alternate furrow irrigation with different irrigation intervals for maize (Zea mays L.). Plant. Prod. Sci. 8: 592-600. https://doi. org/10.1626/pps.8.592

Shahnazari, A., F. Liu, M.N. Andersen, S.E. Jacobsen and C.R. Jensen. 2007. Effects of partial root-zone drying on yield, tuber size and water use efficiency in potato under field conditions. Field. Crop. Res. 100: 117-124. https://doi.org/10.1016/j.fcr.2006.05.010

Shani-Dashtgol, A., S. Jaafari, N. Abbasi and A. Malaki. 2006. Effect of alternate furrow irrigation (PRD) on yield quantity and quality of sugarcane in southern farm in Ahvaz. Proceeding of national conference on Irrigation and Drainage Networks Management. Shahid Chamran Univ. of Ahvaz. 2-4 May, Pp: 565572. [In Farsi].

Sleper, D.A., S.L. Fales and M.E. Collins. 2007. Foreword. In: Irrigation of agricultural crops (R.J. Lascano and R.E. Sojka, eds.), 2ndedition, Agron. Monogr. no. 30. ASA-CSSA-SSSA Publ.p. 664.

Speirs, J., A. Binney, M. Collins, E. Edwards and B. Loveys. 2013. Expression of ABA synthesis and metabolism genes under different irrigation strategies and atmospheric VPDs is associated with stomatal conductance in grapevine (VitisviniferaL. cv Cabernet Sauvignon). J. Exp. Bot. 64: 1907-1916. https://doi.org/10.1093/ jxb/ert052

Steel, R.G.D., J.H. Torrie and D. Dickey. 1997. Principles and procedure of statistics. A biometrical approach 3rd Ed. McGraw hill book Co. Inc., New York. pp: 352-358.

Stikic, R., S. Popovic, M. Srdic, D. Savic, Z. Jovanovic, L.J. Prokic and J. Zdravkovic. 2003. Partial root drying (PRD): a new technique for growing plants that saves water and improves the quality of fruit. Bulg. J. Plant. Physiol. 29: 164-171.

Stoeva, N. and K. Kaymakanova. 2008. Effect of salt stress on the growth and photosynthesis rate of bean plants (Phaseolus vulgaris L.). J. Central. Euro. Agric. 9: 385-392.

Taiz, L. and E. Zeiger. 2006. J. Plant. physiol. Sinauer Assoc. Inc., Publ. p. 764.

Tang, L.S., Y. Li and J. Zhang. 2005. Physiological and yield responses of cotton under partial root zone irrigation. Field. Crop. Res. 94: 214-223. https://doi.org/10.1016/j.fcr.2005.01.005

Wakrim, R., S. Wahbi, H. Tahi, B. Aganchich and R. Serraj. 2005. Comparative effects of partial root drying $(\mathrm{PRD})$ and regulated deficit irrigation (RDI) on water relations and water use efficiency in common bean (Phaseolus vulgaris L.). Agric. Eco. Environ. 106: 275-287. https://doi.org/10.1016/j.agee.2004.10.019

Wang, L., De Kroon, H., B€ ogemann, G.M., Smits, A.J.M., 2005. Partial root drying effects on biomass production in Brassica napus and the significance of root responses. Plant Soil. 276: 313-326.

Wilhite, D.A. and M.B. Smith. 2005. Drought as hazard: Understanding the natural and social context." In drought and water crises: science, technology, and management issues, edited by D.A.Wilhite, CRC Press,U.S.pp:3-29. https:// doi.org/10.1201/9781420028386.pt1

Wu, Y.L., Q.F. Guo, Y. Luo, F.X. Tian and W. Wang. 2014. Differences in physiological characteristics between two wheat cultivars exposed to field water deficit conditions. Russ. J. Plant Physiol. 61: 451-459. https://doi. org/10.1134/S1021443714030157

Xue, Q.W., Z.X. Zhu, J.T. Musick, B.A. Stewart and D.A. Dusek. 2006. Physiological mechanisms contributing to the increased water use efficiency in winter wheat under deficit irrigation. J. Plant Physiol. 163: 154-164. https://doi.org/10.1016/j.jplph.2005.04.026

Yang,J.C.,J.H.Zhang, Z.L.Huang, Q.S. Zhu and L. Wang. 2000. Remobilization of carbon reserves is improved by controlled soil-drying during grain filling of wheat. Crop Sci. 40: 1645-1655. https://doi.org/10.2135/cropsci2000.4061645x

Yazar, A., F. Gokçel and M.S. Sezen. 2009. Corn yield response to partial root zone drying and deficit irrigation strategies applied with drip system. Plant. Soil. Environ. 55: 494-503. https://doi.org/10.17221/96/2009-PSE

Zegbe, J.A., M.H. Behboudian and B.E. Clothier. 2004. Partial root-zone drying is a feasible 
option for irrigating processing tomatoes. org/10.1016/j.agwat.2004.04.002

Agric. Water. Manage. 68: 195-206. https://doi 